\title{
1 \\ The Seven Dwarfs: A Team of Rivals
}

\author{
Nicholas Brown
}

The persistence of the idea of the 'seven dwarfs' in the fairly thin soil of Commonwealth Public Service (CPS) history testifies to its usefulness - although just as the actual composition of the group remains a matter for debate, so does the question of their significance continue to prompt varied interpretations. In a general sense, the term is well enough understood. The expression, 'seven dwarfs', refers to the careers and characteristics of a group of men who secured great influence and authority within and around the CPS from the 1940s until, in some cases, well into the 1980s. They represented a marked expansion in the reach, standing and professionalism of public policy in Australia. They are also a neat encapsulation of 'the new mandarins' - a wider company of senior bureaucrats - who rose to prominence in that period, and were associated with a distinct ethic of independence and authority.

As a descriptor, then, the term is fairly settled. But the explanations it embodies are less agreed. Not only the individuals concerned but also the starting point for their ascendancy varies in accounts, depending on the emphasis given to internal factors within the CPS (recruitment, mentorship, opportunity), external factors (the role of elected governments, the impact of major events such as the Great Depression and the Second World War, or of ideas such as Keynesianism), and the interplay between them. More important, perhaps - although a good deal less discussed - is how to mark the end of their 'period'. At what point can the distinctive combination of factors they reflected - the 'age' of these mandarins - be said to have 'passed'?

It is notable, for example, that in the surge of CPS 'reformism' that commenced in the early 1980s, the scrutiny of an allegedly pervasive inefficiency, rigidity and insularity reached back usually within a 20-year span of memory or political purchase. As the prime minister, Bob Hawke, declared in 1986:

The Public Service has, in many ways, reflected the easy-going, 'she'llbe-right-mate' management and work style of the lucky Australia of the 1960 s and 1970s. We can afford this no longer. ${ }^{1}$

1 R.J.L. Hawke, Commonwealth Parliamentary Debates, House of Representatives, 25 September 1986, 1448. 
Before that, and perhaps untouchable in terms of collective or institutional memory, or deemed irrelevant to political bargaining over the reach and repercussions of government from the 1960s onwards, was the land of the seven dwarfs. How are we to understand the transition both in to, and out of, that land? From this perspective, the endurance, and usefulness, of the dwarfs' story is not just the CPS folklore it is sometimes seen to be. It also raises questions about how we are to understand the changing relations between government, politics and society in Australia.

Most contributors to this collection engage with these questions in ways arising from a close study of individuals who were either likely members of the company of dwarfs, or who presided as mandarins - figures who acquired high bureaucratic office on the basis of exactingly examined merit - over that transformation within the CPS. Stuart Macintyre, in the next essay, considers how formative the context of wartime management and especially post-war reconstruction was for this cohort. My task is to set a different kind of context. What was the nature of the networks in which these figures became so prominent, and how might the relationships between them help us understand their significance as a group? In particular, I want to outline what came to be understood and expected of the figure of the senior public servant in those years: the range of roles, skills, behaviours and attitudes associated with that figure, as exemplified by the dwarfs. Rivalry, as my title suggests, was as much a characteristic of those relationships as cohesion, and underscored the extent to which these individuals were making their context on the basis of highly personalised resources and recognition rather than simply finding roles within established institutions.

From this perspective, it is important also to consider the character of the community and institutions within which these figures worked - the Canberra that suddenly, if austerely and incompletely, acquired the status and functions that might at last be said to be appropriate for a national capital; and the institutions that were charged with the functions of an equally sudden, austere and incomplete new vision of national government. This was the dwarfs' landscape, and one in which we might begin to understand their historical significance, even in the larger pursuit of that endemic Australian 'blood sport' (so it seemed to the 1983 Review of Commonwealth Administration) of rubbishing the CPS. ${ }^{2}$

Just to remind ourselves that there is nothing new to this sport, in April 1945 the Sydney Morning Herald unkindly quipped that:

If V-2's had completely obliterated London, surviving Londoners could have built elsewhere a city that in tradition and spirit would again be

2 Review of Commonwealth Administration, Report (Canberra: AGPS, 1983), $\mathrm{x}$. 
London. If similar disaster overcame Canberra, surviving Canberrans would emerge as a flock of homeless people without real ties of common interest other than nationality and community in distress. ${ }^{3}$

A good deal of what has been invested in the 'seven dwarfs' and their period hinges on an attempt to rebut such an assessment. As an idea, the dwarfs assert that the Canberra, and the CPS, that emerged from the Second World War had undergone a qualitative as well as a quantitative change, and acquired a marked competence, if not quite a 'tradition and spirit'. Commentators in the early 1940s lamented that Australia had been forced to cobble together an 'all in' war effort in 'the absence of an effective Federal seat of government' due to the long-term 'passive resistance' of many interests to all that Canberra might be. ${ }^{4}$ Towards the decade's end it was argued instead that improvements in the capacity and quality of Australian government 'may be expected as [it] ... becomes more diversified [and] firmly rooted in an alert Canberra community'. ${ }^{5}$ Self-serving that last assessment might be - it came from Dr P.W.E. Curtin, an official who benefitted from being a part of that emerging community. But this transition nonetheless suggests some of the ways in which we might assess the collective significance of the individuals studied elsewhere in this book, and from my particular perspective - how we might characterise (in Tim Rowse's formulation) the 'competitive collegiate' ethic they established in government. ${ }^{6}$

There is, however, a fundamental question to be addressed first. Who were the seven dwarfs? At one level, to pose this question is to risk being drawn back into CPS nostalgia. As John Nethercote has observed, debate over the names to be included in their ranks has long been standard fare at national capital dinnerparty conversations, the pre-occupation of Canberra aficionados and tragics. So, too, has been the question of when the term itself was first coined. Responses to the announcement of the conference on which this book is based proved that these issues still cause a measure of perturbation. Reputations and legacies are in the balance, especially in a city in which even street addresses were, not too long ago, read as rankings of CPS seniority. And, perhaps more fundamentally, up for grabs in finalising the cast are characterisations of the inner circles, and the core functions and ideas, of government during a period of pronounced change.

The enumeration of the company in itself influences how we are to account for its significance - for its nexus between the talents, personalities and commitments of individuals, and a context punctured by major events: depression, war, and not least the change of government in 1949. At one end of the spectrum, there was a depth of personal experience common to most of the contenders. They

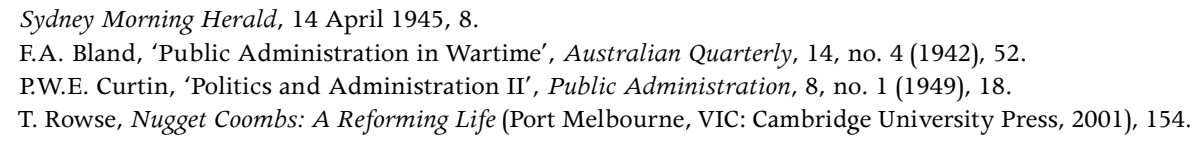


came from relatively modest backgrounds, scholarship educations, and were products, as John Crawford (one undisputed member of the group) put it, of 'the thirties when our minds were beset by problems of the depression, of social misery and of threatening events on the world scene'. ${ }^{7}$ Bright, direct, defiant in insisting (as Roland Wilson, another certain member, stated) on never ignoring 'the voice of the people' in dealing with the cautions or ambitions of politicians, they worked with an expansion of public policy into new areas of economic and social management, and geared towards ensuring that such crises did not return. ${ }^{8}$

The stamp of the 'Keynesian Crusade' - H.C. Coombs' term (he is also a sure bet for a place) - was to some extent on them all, if worn over time with varying levels of comfort. ${ }^{9}$ That crusade - going well beyond questions of economic management to images of social progress - defined the frontiers they often broached as individuals, not only in policy but in new ways of behaving in often unprecedented contexts. If they were products, as mandarins should be, of meritbased education systems, those systems in themselves were far from entrenched at the time of their ascendancy. Each of the figures discussed in this book benefitted from initiatives taken by schools and universities, and in newly consolidating academic disciplines such as economics, to redress a paucity of knowledge and skill amid the crises of the time. And such training still stood in a rather equivocal relation to established structures of government, which were only overcome under the pressure of extreme circumstances. The image of the 'seven dwarfs' is often, in retrospect, one of mature men, advanced, secure, wise and worn in their careers. They rose, however, on the wave of a desperate search - in the aftermath of the First World War - by teachers, academics and then official mentors to find in a younger generation some redress to the heavy hand of the old. ${ }^{10}$

Balanced against this emphasis on personal experience and commitment is a characterisation of the bureaucratic systems that the dwarfs came to exemplify. In moving from nine years of wartime and reconstruction mainly under Labor into an unprecedented 23 years under the Coalition parties, the dwarfs were associated with a paradigm of public service neutrality and impartiality. For figures who, in several cases especially, were closely associated with Labor's post-war agenda, their acceptance by a new government, with an explicitly contrasting free enterprise ideology, was testimony to another set of qualities. Navigating this transition after 1949 itself made a priority of strict professionalism. Into the post-war decades, over and above their individual attributes, they were

7 J. Crawford, University and Government (Canberra: Royal Institute of Public Administration, A.C.T. Group, 1969), 2.

8 R. Wilson, quoted in S. Cornish, Sir Roland Wilson: A Biographical Essay (Canberra: Sir Roland Wilson Foundation, ANU, 2005), 30.

9 H.C. Coombs, Trial Balance (Melbourne: Macmillan, 1981).

10 See N. Brown, Richard Downing: Economics, Advocacy and Social Reform in Australia (Carlton South, VIC: Melbourne University Press, 2001), 42-43. 
increasingly seen to have embodied the concept and responsibilities of the 'permanent head' of government departments. And they invested this position with its own pragmatism and power. The role of the permanent head might have demanded (as Frederick Wheeler, a central mandarin but not a dwarf, dryly noted) 'an onerous career involving much self-denial'. But its performance was also the stuff of the legend surrounding these figures, of the power of 'Canberra' and the authority of government associated with them at its pinnacle. ${ }^{11}$

In this interplay of personalities and processes, as well as between internal CPS and external intellectual and political influences, the identity of the dwarfs has been debated for years, and related back to tensions in the group itself. Were there contests between - to take an example flagged by Nethercote - those for whom the primary purpose of public policy was to generate growth as a reward for enterprise, and those with an eye to the more equitable distribution of the gains from that growth? Or - anticipating later debates about the representativeness of the CPS - over the insularity of 'Canberra', and the dominance of influences such as a 'Treasury line' in the making and implementation of policy? Or more simply about the competition for resouces - including for people, and in turn for influence - in the very constrained environment that was Canberra until at least the 1960s. For a group identified collectively with a transformation of the CPS in general, they have also gone down in history and myth individually as 'great haters', deeply resentful of the claims each other made for their specific terrain. ${ }^{12}$ Is it possible to bring any resolution to these tensions and questions?

Early in the 1990s, Geoffrey Bolton instigated a poll on the question of who were the seven dwarfs at a time when more of those with some first-hand acquaintance with the phenomenon were still able to contribute. Yet even then, it would seem from an extensive correspondence between Bolton and many others, to some extent mediated by the Australian Dictionary of Biography, no clear contingent emerged. ${ }^{13}$

The names that were canvassed in this exchange are familiar enough, although some shoot quicker across the sky than other more constant stars. A consolidated list of contenders includes Coombs, Wilson, Crawford, Wheeler, Richard Randall, Allen Brown, Henry Bland, Frederick Shedden, Trevor Swan, Frank Strahan, Kenneth Bailey, William Dunk, Jock Weeden and Stan Carver. In itself, this is an interesting field, indicating areas of government identified as potentially fitting within the matrix of factors associated with the dwarfs. Many, however, can be set aside fairly quickly - again, in a process of elimination that is revealing of the boundaries set for the dwarfs and their significance.

\footnotetext{
11 F.H. Wheeler, 'The Professional Career Public Service: Some Reflections of a Practitioner', Australian Journal of Public Administration, 39, no. 2 (1980), 165.

12 R. Beale, quoted by P. Shergold, Once was Camelot in Canberra? Reflections on Public Service Leadership, Sir Roland Wilson Foundation Lecture, 2004 (Canberra: The Australian National University, 2005), 3.

13 The following draws on a file of correspondence and clippings, kept by Bolton and in possession of the $A D B$.
} 
Strahan, head of the Prime Minister's Department until 1949, and a confidante of several prime ministers, had few backers in Bolton's poll; he described himself as 'just a clerk', and cannot be associated with the transition from Labor to the Coalition in power, which is central to the collective identity of the 'dwarfs'. So he can be scratched fairly quickly. So can Bailey. Secretary of the AttorneyGeneral's Department (1946-64) and solicitor-general (1946-65), he was a significant figure in advising government on the legality of the powers sought in the expanding domain of Commonwealth legislation. But - in addition to being judged too tall by Robert Parker, an ANU political scientist who knew the field well - Bailey did not have the instrumental engagement with policy that came with dwarfdom.

Dunk, briefly secretary of External Affairs (1945-47), then chairman of the Public Service Board (1947-60), was also too tall and mostly outside direct engagement with the high policy, if not the intrigue, of Canberra. Dunk's mantra, 'civilisation is management', expressed his commitment to the rejuvenation of a 'run-down' post-war CPS, but a good deal of his time was spent in managing both the political and industrial strains of seeking such improvement rather than with the processes of policy reform itself. ${ }^{14}$ Weeden, who guided the Commonwealth's move into education, was deemed to lack the highly desirable qualification in economics that characterised most of the dwarfs, but also to work in a field that was not sufficiently central to the core policy priorities of the time. Swan, while undeniably an influential economist closely in touch with those priorities, moved to the fledgling Australian National University in 1950 with the hope that some research-government fusion might develop, but this never happened. Whatever the extent of his back-door or 'brown bag' advice to government through the 1950s, he stood on one side of the divide between academic analysis and policy professionalism that was increasingly deeply scored in Canberra through those years. Swan was nominated by Sir Harold White, who was an ambitious advocate for his own bastion, the Parliamentary and National libraries. Certainly canny, White has also sometimes been mentioned as a possible dwarf - but he at least did us the service of declining inclusion in the corps.

Confounded by such a list of contenders, Parker suggested that the play of the concept was perhaps more important than a settled company. Even so, such a first cut gets a good deal closer to a manageable list of names and claims. Building on such possibilities, and spurred by Bolton's inquiry, the Canberra Times confidently declared in 1992 that the team was:

- Crawford: Post-War Reconstruction, then secretary of both Commerce and Agriculture (1950-56) and Trade (1956-60)

14 N. Brown, 'Dunk, Sir William Ernest (1897-1984)', Australian Dictionary of Biography, 17 (Melbourne: Melbourne University Press, 2007), 345-6. 
- Bland: director-general of Manpower then secretary of Labour and National Service (1952-67)

- Wilson: secretary of Labour and National Service (1940-46), then Commonwealth statistician (1946-51) and secretary to the Treasury (1951-66)

- Randall: Treasury, succeeding Wilson as secretary (1966-71)

- Coombs: director-general of Post-War Reconstruction, then governor of the Commonwealth Bank (1949-59) and Reserve Bank (1960-68)

- Carver: Commonwealth statistician (1951-62)

- Brown: Post-War Reconstruction, then secretary of Prime Minister's Department (1949-58).

Yet, averaging out the 'hits' in Bolton's poll, the most preferred company is:

- Coombs

- Wilson

- Crawford

- Brown

- Bland

- Randall

- Shedden: secretary, Department of Defence (1937-56).

In one of the few instances of a contender actually associating himself with the company, Bland gave Crawford, Randall, Wilson, Coombs, Brown, Carver and himself as the definitive list, citing as the formative context a working party established in 1947 to serve the Investment and Employment Committee, with Chifley as chairman, and a brief to get to grips with the reality of post-war government. ${ }^{15}$ But the exclusion of Shedden from Bland's account is problematic, and Carver does not rate a place in more recent 'official' guides. ${ }^{16}$ In a sign of how contested the last seat on the bench could be, the $A D B$ itself questioned Carver's standing as a possible 'dwarf' by describing him as 'essentially a statistician' ${ }^{17}$ Equally, while Shedden rather than Carver figured in a profile of 'The Biggest Little Men in Australia' published in the Financial Review in 1965, that profile also noted that his 'inclusion is usually regarded as being mainly coincidental in that he was a department head and happened to be about the same physical size as the other six'. ${ }^{18}$

15 Australian, 21 January 1967, 9; Sir Henry Bland, interviewed by Mel Pratt, 8-10 January 1975, National Library of Australia (NLA) TRC 121, 60.

16 J. Adams and C. Oates, Serving the Nation: 100 Years of Public Service (Canberra: Public Service and Merit Protection Commission, 2001), 146-7.

17 M. Kerley, 'Carver, Sir Stanley Roy (1897-1967)', Australian Dictionary of Biography, 13 (Melbourne: Melbourne University Press, 1993), 93.

18 Financial Review, 12 November 1965, 2-3. 
The Seven Dwarfs and the Age of the Mandarins

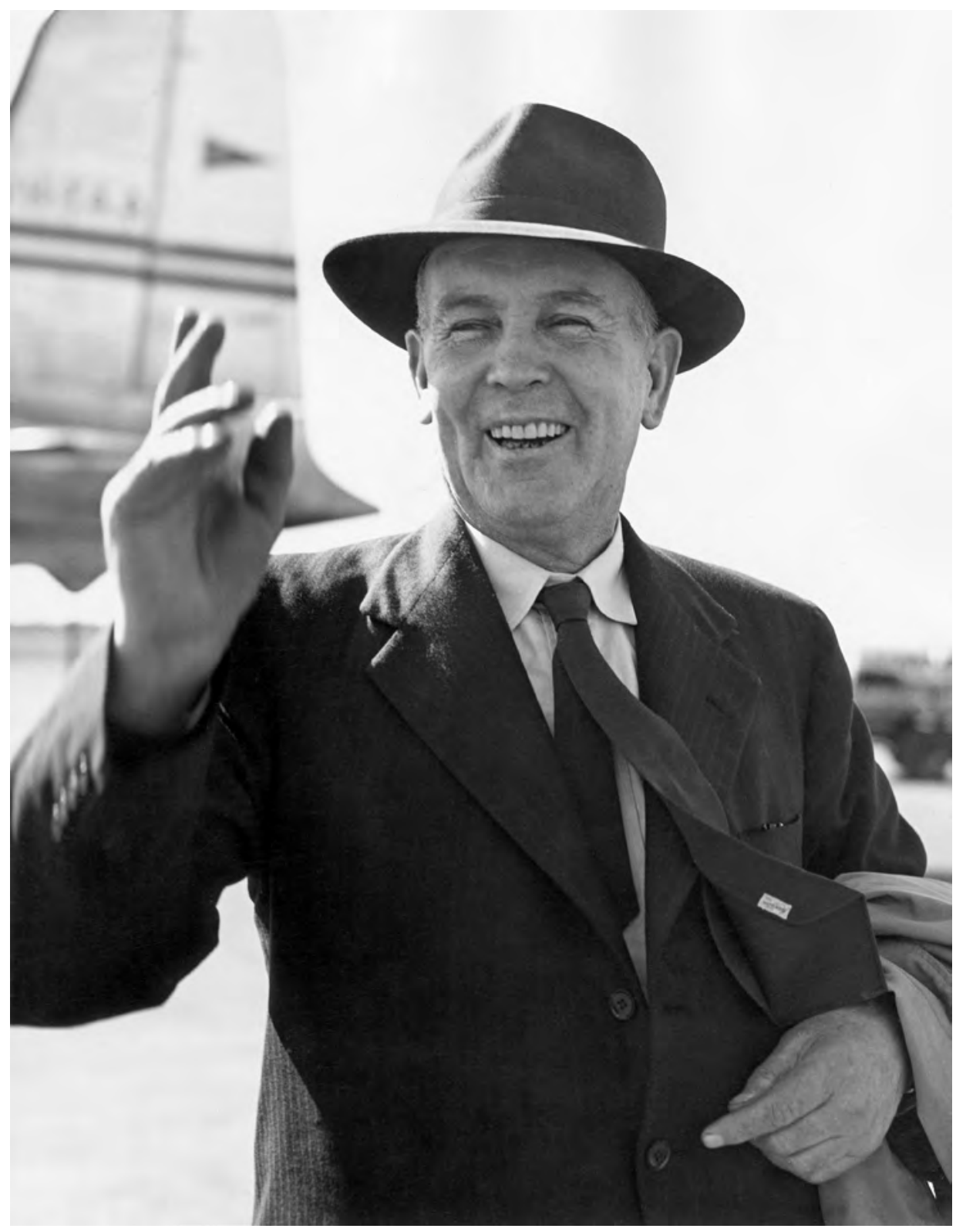

J.B. (Ben) Chifley, c1949

Source: National Archives of Australia, A462, 778/03 PART 2 
The various permutations of this list perhaps in themselves reflect rivalries among candidates - and no doubt the debate will continue, spurred once again by this collection of essays. But, drawing this particular auction to a close however provisionally - the most likely seven are (in a rough order of certainty): Coombs, Wilson, Crawford, Brown, Bland, Randall, and Shedden.

Likely - but perhaps not all equally deserving. In one of the clear signs of competition for recognition, or just plain bitchiness, David Horner quotes Arthur Tange - secretary of the Department of External Affairs (1954-65), certainly a mandarin but not a dwarf - saying of Shedden that he fulfilled the dictionary definition of 'bureaucrat': 'an official who works by fixed meetings without exercising intelligent judgement' ${ }^{19}$ That might have been the insider's perspective, and reflective of the tensions developing between an External Affairs department self-consciously preening its intellectual ascendancy and a Defence establishment a good deal more 'grounded' in its business. It is also worth noting in passing a more populist perspective of 1964, which praised Carver as the only public servant who at least had a tangible output, being the 'figure-juggling juggernaut' in charge of an agency that could tell the nation something useful about itself. Carver's command of the facts of population, productivity and prosperity was then contrasted by journalist Frank Clune to higher-minded public servants who were consumed in a 'vast amount of political and social manoeuvring and rumours': 'If you want to see the Australian ruling class', Clune concluded, 'go to Canberra. The air of life here is superannuation.' ${ }^{20}$

Already, these variations on the list of dwarfs suggests something of what was at stake in being included. One qualification is indisputable: the Financial Review gave the height range for its selection as running from Wilson at 5 feet $(152.4 \mathrm{~cm})$ and 9 stone $(57 \mathrm{~kg})$ to Coombs at 5 feet 3 inches $(160 \mathrm{~cm})$ and 10 stone $(63.5 \mathrm{~kg})-$ roughly the height of the average Spanish man of the 1950s. But, beyond shared stature, what does such a list suggest?

As argued already, what rides on the shoulders of this group is a characterisation of a - if not the - major period in the consolidation of the CPS. And, as also already noted, there are two central elements to this consolidation - personal attributes and experience, and professional role - that do not necessarily sit easily together. The groupings offer one way into figuring out how the tensions between these elements were managed at the time, and might be evaluated in retrospect.

Turning to that first element: personal experience and commitment. The seven dwarfs symbolise the transformation of government under the pressures of the

19 Tange, quoted in D. Horner, Defence Supremo: Sir Frederick Shedden and the Making of Australian Defence Policy (Sydney: Allen \& Unwin, 2000), 7.

20 F. Clune, Journey to Kosciusko (Sydney: Angus and Robertson, 1964), 245-6. 
Second World War, both in the rapidly centralised functions and expanding reach of what in 1939 was termed the Federal Government but by 1945 was the Commonwealth, and in the recruitment of specifically identified expertise to manage these processes. ${ }^{21}$ This element is exemplified by the Keynesian paradigm: government transformed by young, university-trained, and theoretically informed reformers. These figures sought to translate a broad domain of civic concern formed in contexts of depression and unemployment into careers spent dealing with pressures first of wartime mobilisation and reconstruction, then of inflation and full employment, and with the expanding role of public investment in general. These iterations developed their own tensions as well as ideals. As Weller, Scott and Stevens put it, 'peace and prosperity engendered expectations and hope among public servants that they could improve conditions for the community' ${ }^{22}$ But in the process, some aspects of that paradigm in themselves came under strain. Not least among these aspects were the judgments made in attributing relative weightings to the virtues practised in public and private spending and saving, work and enterprise, to the old solidarities of labour and class, the new claims of enterprise and welfare, or the ideals of citizenship and security. These weightings went beyond calculations of economic growth or national income in determining the merits or impact of policies on a society in itself posing new issues for government. In responding to these issues, the postwar mandarins were learning and testing themselves and their convictions as they went.

These men were emphatically not the economic rationalists of the 1980s, with their deference to the discipline of the market. They were instead conscious as Coombs would put it - of using 'other people's money' to achieve a range of social outcomes within the context of a tight bargain between stability and growth, prosperity and regulation, the respective roles and responsibilities of the government and the people. ${ }^{23}$ Crawford is recalled for the restrained bitterness with which he spoke of those bureaucrats to whom the poor and the unemployed were not persons but simply component figures in a statistical index' ${ }^{24}$ That tension was implicit within their shared professionalism: how was it best to evoke the society over which they exercised influence?

As Harold Perkin has argued, public service professionalism through the twentieth century developed in an unsteady bargain between 'an old loyalty to class-based politics', embodied in ideas of 'service', and a rising ethic of

\footnotetext{
21 See F. Brennan, Canberra in Crisis (Canberra: Dalton, 1971), 150.

22 P. Weller, J. Scott and B. Stevens, From Postbox to Powerhouse: A Centenary History of the Department of Prime Minister and Cabinet (Sydney: Allen \& Unwin, 2011), 48-9.

23 H.C. Coombs, Other People's Money: Economic Essays (Canberra: Australian National University Press, 1971).

24 O. Spate, 'Sir John Crawford (1910-1984)', Obituaries Australia, National Centre of Biography, The Australian National University, oa.anu.edu.au/obituary/crawford-sir-john-grenfell-jack-1391/text1390, accessed 13 September 2011.
} 
'equality of opportunity', relating more to formations of the 'public' to be served, or represented. ${ }^{25}$ The post-war social contract was informed by an increased negotiation of these values, albeit with its own Australian inflections. One of its leading exponents, R.I. Downing, who had his own place in the 'official family' of advisers that grew around the Labor Government in Canberra in the 1940s, and in the 'Keynesian crusade', phrased it from his Melbourne academic vantage in 1956 in these terms:

This is precisely what we are trained for - to identify what it is we have to give up, and how much, in order to get a little more of something else we want; to present the facts to the people; and to leave them to choose what they want. ${ }^{26}$

The dwarfs presided over a model of government framed by that sense of responsibility, that idea of managing the needs and demands arising from a pluralistic if regulated society: to 'present the facts' if not persuade on 'the wants', and to mark out an appropriate domain of 'choice'.

Equally, in that same address to a Canberra audience, Downing could not resist the parting shot: 'In my strictly personal platform for economic policy, in fact, my main plank is the abolition of Canberra. You all ought to come back and live with us'. That aside touches on the second element of the dwarfs' landscape: the entrenching of concepts of public service professionalism into the practices of policy development, ministerial advice and public responsiveness in the context of a marked expansion of central government.

Patrick Weller has offered a neat summary of this professionalism from the time of the dwarfs: 'the official adviser, buoyed with expertise and knowledge, bolstered by a monopoly of access, dominating many of the ministers' ${ }^{27}$ This was the domain of the 'mandarin' - the figure who not only exercised a considerable element of control over what was 'left' to 'the people' to choose, but also over what went to the minister to decide. And this practice permeated deeply into departmental cultures, with a range of effects.

After 1939, telegraph boys were increasingly unlikely to rise to the top of the public service, but scholarships boys - so the dwarfs showed - had a better chance, and steadily, if slowly, so did university graduates in general. From the margins of dwarfdom, a figure such as Dunk recognised this as he lobbied for public service reform through the 1950s. Without a university degree himself, he conceded that his generation of managers must effectively ensure their own

25 H. Perkin, The Rise of Professional Society: England Since 1880 (London: Routledge, 2001), 517.

26 R.I. Downing, 'Is an Economic Policy Possible?', Australian Journal of Public Administration, 15, no. 4 (1956), 273-4, 281.

27 P. Weller, Australia's Mandarins: The Frank and the Fearless (Sydney: Allen \& Unwin, 2001), 9. 
obsolence given the demand for new policy skills. In the first stages of this process, however, a distinct, perhaps more innately competitive ethic characterised Commonwealth departments at the forefront of policy development.

Always conscious, in their inter-war educations, of insecurity in the lives around them, and of the rare opportunities extended to them, the dwarfs imbibed certain precepts about the work of government. They understood both its powers (which were not to be exploited in ways that - as the 1930s showed-could fail, resulting in waste and unrest) and its privileges (from which they benefitted, but which were not to be assumed or exploited). Even in the resistances they faced in bringing their expertise into systems still largely defined by seniority and its tribalisms, they realised that the structures of government were to be worked with (or at least within), not challenged. As Wheeler - who would savour these processes more than most - reflected in 1980, the senior 'professional, career public servant' (each of those terms mattering exactly to him) was 'richly rewarded by the fascination of being associated with the political while not being of it' ${ }^{28}$ For all their conspicuous markers of higher education, the dwarfs would often make their way with a reflex rejection of ideology and abstraction. Their role was to ensure the system worked as efficiently and effectively as possible: they were its creatures, not the other way around. They were also its custodians, and gatekeepers.

Even so, there was a qualification, or a twist, to this relationship. Paul Hasluck - not a dwarf, but potentially a mandarin until his own turn to politics in that climactic election of 1949 - observed what he took to be a distinctly Australian phenomenon of the immediate post-war decades. Well-educated public servants, he argued, now found themselves dealing with politicians who had risen to ministerial rank but tended to lack an education 'comparable to that of their advisers' ${ }^{29}$ Such a disjunction was new, and enhanced the power of the dwarfs. The structures of government within which they worked were not seen as theirs by right, but theirs to influence, guide and protect. Again, as Hasluck noted of the connection between the public servant and politics, with his own slant on the fascination observed by Wheeler, 'one has to recognize that a policy decision does not freeze politics [to the extent it must be taken into account by the public servant], but only turns political energy into the chosen direction', which it then became the public servant's responsibility to pursue. ${ }^{30}$ The domain of the senior public servant was newly energised by these responsibilities in the expanding compass of post-war government.

28 Wheeler, 'The Professional Career Public Servant', 165.

29 P. Hasluck, The Public Servant and Politics (Canberra: Royal Institute of Public Administration, A.C.T. Group, 1968), 15.

30 Ibid., 3. 
Importantly, these distinctions were not just learnt on the job; they were part of the education that an inter-war generation tested as they journeyed forward. 'A bureaucracy', Henry Bland's father, Professor F.A. Bland, wrote in a 1923 Workers' Education Association textbook on government in Australia (a book itself addressing the scarcity of any local work reflecting on these issues), 'is mainly distinguishable by its irresponsiveness to the public will'. To that extent, for those schooled on Bland's textbook and the larger British and American literature on which it drew, 'bureaucracy' was to be unfavourably distinguished from the more plain-spoken, plain-acting concept of 'public administration', dealing more directly with matters of policy implementation, not policy formation. Bland further cautioned that:

The development of an expert official class, the multiplicity of departments, their imperfect coordination, the impossibility of adequate ministerial supervision, the unwillingness of Parliament to adapt its procedure to modern economic and social needs, all tend to widen the gulf between expert officialdom and the public. ${ }^{31}$

Dealing with that 'gulf' - even if implicitly rejecting it as anachronistic-required careful footwork. When Roland Wilson (with two doctorates in economics) was appointed secretary to the Treasury in 1951, the move was seen as 'the first Australian experiment of this kind' - a perception that Wilson moderated by offering the assurance that he would 'never be guilty of ignoring the voice of the people'. He also undertook 'to subject my thinking to the supervision of my political masters', a discipline necessary to correct for the tendency of 'some of our public service administrators ... [to become] too much infatuated with their own crack-pot ideas' ${ }^{32}$ But, from the late 1940s and into the 1950s, each side of this bargain - the 'people' and the 'masters' - were often far from stable entities. 'Frank and fearless advice' was itself premised on an expertise that transcended the flux of opinion and politics. The transition of 1949 highlighted this - new Liberal ministers reportedly finding themselves 'completely incapable of coping with the voluminous duties' that represented the changed dimensions of policy through the 1940s, and equally wary of advice from those who had served the previous government, and on questions that saw divergent options on those issues of enterprise or equity, distribution or growth. ${ }^{33}$ None of the dwarfs is remembered for doing what they were told by ministers still finding their feet. They are, instead, remembered for the innovation, the consolidation and the character they brought to the tasks of and demands on government as it weathered such transformations.

\footnotetext{
31 F.A. Bland, Shadows and Realities of Government (Sydney: WEA, 1923), 5.

32 Wilson, quoted in S. Cornish, Sir Roland Wilson: A Biographical Essay (Canberra: The Sir Roland Wilson Foundation, 2002), 30.

33 Inside Canberra, 12 January 1950, 8 June 1950, 26 October 1950.
} 
Each of the individuals studied in this book draws out specific aspects of these elements in transition. Some are intangible. Wheeler, for example, emphasised the concept of 'style' - manner more than matter - when he came to reflect on what defined the most effective senior officials in his experience. ${ }^{34}$ And - if not quite style in itself - a certain brusque efficiency and impatience seems to have characterised many of the dwarfs in their personality, and their determination that the work of government take place in a domain clearly demarcated from the flux of mere opinion or politics, and in departments that they ruled closely. Overwork was no doubt part of the explanation for that terseness - and the demands of their jobs were never far from candid exchanges among them. But such a demeanour was also cultivated as an expression of the responsibility they carried, and the terms in which they carried it. Allen Brown - one of the two lawyers among the dwarfs (the other was Bland) - was noted by the Australian in 1971 as having the reputation as 'a ruthless, abrupt administrator'. The London Times was a little softer, welcoming him in 1959 as Deputy High Commissioner in Australia House at end of his time at the Prime Minister's Department:

Wiry and normally placid, and neither hearty nor arty, he is a much more than fair sample of highly professional civil servants developed in Canberra. ${ }^{35}$

If part of the success of the dwarfs was that - as John Bunting (Brown's successor in Canberra) put it - they were 'companions' to Sir Robert Menzies as an equally shrewd, enduring prime minister (and presumably their Snow White - he himself was heard to claim this role), it was also the case that each carved out a formidable authority of their own. ${ }^{36}$ 'Neither hearty nor arty' reflects something of that careful cultivation - perhaps in that particular instance filtered through a British search for a way of comprehending this new kind of Australian on the Strand. Not all were as 'naturally taciturn' as Brown, but the Times' sense of a type is revealing. All faced the challenge of securing support for the business of national government that was often under scrutiny for its partiality, its extravagance, and its distance from the 'reality' of the rest of the nation.

34 Wheeler, 'The Professional Career Public Servant', 162.

35 Australian, 28 September 1971; Times, 3 January 1959.

36 H.W. Arndt to G. Bolton, 27 February 1992; Bunting, quoted in Adams and Oates, Serving the Nation, 146; Weller, Scott and Stevens, Postbox to Powerhouse, 52. 


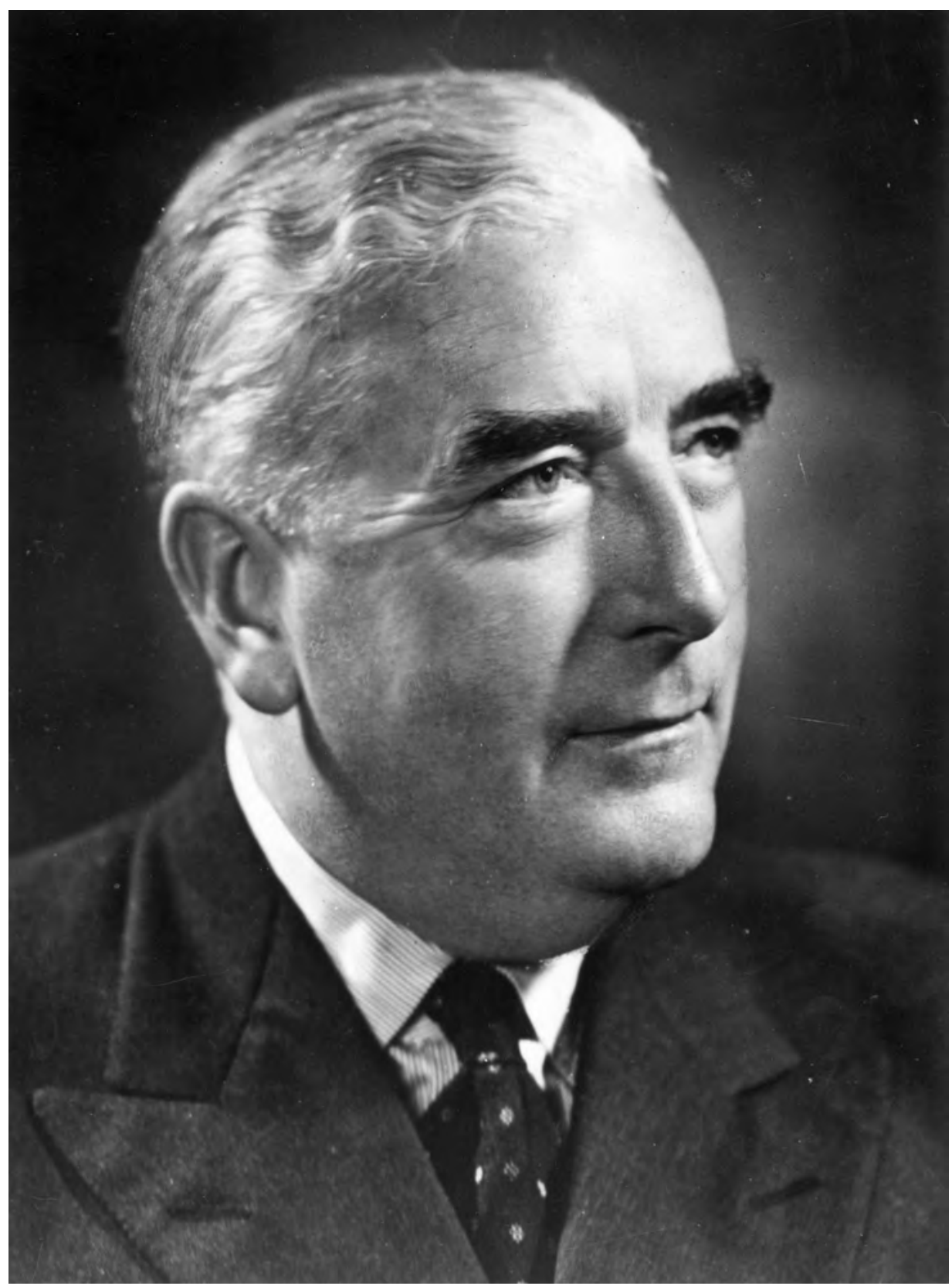

Robert Menzies, c1950

Source: National Library of Australia, nla.pic-an12265907 
The Department of Post-War Reconstruction, which bulked large in many careers as an emblem of the new reach of government, became in itself an object of planned obsolescence in this process, even under a Labor government as concerned about trimming the costs of a 'multiplicity of departments' as it was about containing perceptions of its addiction to 'planning'. With solid foundations still in industrial unionism and an ethic of egalitarianism, Labor had no necessary affiliation with big government. In 1946, it gave the task of trimming a wartime accretion of some 60,000 temporary CPS officers to J.T. Pinner, who was renowned for holding building contractors to account by counting the number of empty cement bags around Canberra's new Administrative Building. ${ }^{37}$ Especially in the wake of the failure of the 1944 referendum on Commonwealth powers, the government itself was in no mood for allegations of excess or inefficiency. And with each post-war budget being rumoured, well into the 1950s, as being called to bring, or actually bringing, cuts to the public service, part of the skill of a mandarin was to preserve their domain under such scrutiny. Again, as Wilson made clear to Tange:

What mattered for public servants was how their department was faring in a constant battle for influence. A truly successful public servant was one who led a department that was at or near the top of an imaginary league table. Standing in this table depended on perceptions of the department's strength and influence, particularly in the eyes of senior ministers and other departmental heads. ${ }^{38}$

At a basic level, as the post-war structures of government settled down, there was that inherent rivalry among the company - and it was transacted at the most basic levels of differentials in salary and opportunities for initiative. The announcement of an increase in salary to Allen Brown in 1954, for example, was enough to prompt Crawford to voice candid reservations to his minister, John McEwen, about his future in a service that seemed not to equally value his skills or commitment, and for McEwen to suggest that Menzies as prime minister needed to take note of such disquiet spreading among other largely indispensable permanent heads. As McEwen insisted, the matter was not simply one of ego, it was one of 'dignity' ${ }^{39}$

Beyond such delicate dealings, however, was the more fundamental question of what would define the figure of the public servant through such transitions. In 1923, F.A. Bland had identified the pressing need to attend to the appropriate training of a public servant if the dangers of bureaucracy were to be avoided. His counsel then was that an administrator needed a general,

37 G.E. Pettit, 'John Thomas Pinner', Australian Dictionary of Biography, 16 (Melbourne: Melbourne University Press, 2002), 5-6.

38 Wilson, quoted in P. Edwards, Arthur Tange: The Last of the Mandarins (Sydney: Allen \& Unwin, 2006), 83.

39 McEwen to Menzies, 3 March 1954, NAA M2576/1. 
liberal university education as both 'a protection against the disillusionment which accompanies life's inevitable routine' but also as a way of recognising the social transformation impelled by the First World War. Bland cited the perception of J.A. Hobson in 1921:

Rude, unformed, wasteful energy counted more heavily in the rough and tumble of the world that has passed away. Now, conscious, calculated policies are demanded in all those departments of life in which the struggle for survival and success is carried on.

'Conscious, calculated policies' were not so much matters of expertise, but of reflection and sound judgment, seasoned by a perspective that encompassed a necessary understanding of the strained nature of social cohesion as well as of the endurance of 'disillusionment'. Into the 1930s, the service the dwarfs and their cohorts entered was slowly edging towards benefitting from the kind of scholarship and part-time study provision Bland encouraged. ${ }^{40}$ Such provision would, he hoped (this time quoting the Macdonnell Commission on the British Civil Service of 1915), enable 'the clever sons of poor parents to benefit by University training and thereby enter the Civil Service', so that 'the interests of democracy and of the Public Service can and ought to be reconciled' ${ }^{41}$

And so a few of these Australian 'clever sons' were finding their way up the ladder of an education system that was highly competitive, working through a curriculum that was strong on a meritocratic impulse to select and differentiate', to identify the boys who wanted to 'get on', and to cultivate in the introduction of uniforms, houses and badges - an ethic of loyalty and good citizenship. ${ }^{42}$ Their secondary schooling might have culminated in a leaving certificate that - at least in New South Wales - was characterised as having 'a halo around it as big as a bale of hay and worth about as much', but at least that was some recognition of an educational ideal. ${ }^{43}$ Once through that process, they might proceed to universities - where the dwarfs mostly studied part-time, and for several with interruptions demanded by family or personal economic circumstances - which had also begun to urge bright students to see the public service as a worthwhile career. What was sought was a fusion (again in Macdonnell's formulation, endorsed by Bland) of 'Civil Service' and 'Public Service'. But still this did not necessarily translate into ready opportunities. It was only when senior university economists - such as L.F. Giblin and D.B. Copland - were called to advise on the urgent demands of 'total war'

\footnotetext{
40 See R.D. Scott and R.L. Wetherell, 'Public Administration as a Teaching and Research Field', Australian Journal of Public Administration, 29, no. 3-4 (1980): 480-1.

41 Bland, Shadows and Realities, 17, 30, 34.

42 See C. Campbell and G. Sherrington, Comprehensive Public High School: Historical Perspectives (London: Palgrave, 2006), 30-3.

43 A. Barcan, Two Centuries of Education in New South Wales (Kensington: UNSW Press, 1988), 249.
} 
mobilisation that they could follow through on acts of patronage for their best students. That mentorship shaped several early careers for dwarfs and mandarins, but perhaps also further conditioned a sense of debt, duty, and deference; responsibilities to be bestowed and honoured, continuing in the spirit of the educations they had gained so far. These young men were disciplined and clever, but not encouraged to be simply smart.

In 1939, to take one example, Fred Wheeler was among those select few drawn into the wartime 'kindergarten' of junior officers in Canberra. Copland borrowed Wheeler, whom he had taught as a part-time commerce student, from the State Savings Bank of Victoria - where his placement in the loans arrears department offered its own exposure to the lingering hardship of the 1930s - to work with him as wartime Prices Commissioner, an office established early to contain the black-marketing and distortions of the First World War. Clearly able, Wheeler soon moved to a position as assistant research officer in Treasury. In a Christmas card to Wheeler's wife, Copland reassured her - the gesture itself indicating the depth of personal patronage - that in moving to the Treasury 'Fred has made an excellent impression in the office with the regular men in the Service'. That phrase, 'regular men', suggests something of the ranks into which a figure such as Wheeler, with (as Copland noted) his 'economic training', needed to fit. Copland continued:

If he stays in Treasury he must expect to move slowly in advancement at first, and the atmosphere can't be quite the same as in Price Fixing, nor will the work be quite as exciting or as exacting. I have no doubts as to his ultimate success, but you must always remember that the glittering prizes seem remote at first, and are in fact remote. ${ }^{44}$

These emphases are revealing. Such tactical patience no doubt bred its own instincts of competition and of protecting turf. What was understood, however, was that a career in government might eventually offer its own 'glittering prizes' in recognition and seniority for those who at once 'fitted in' and slowly rose above.

A transformation, of sorts, had clearly begun in framing the ideal of the public servant, recognising the need for the kind of skills and expertise associated with a university education, but also for the balances to be struck in translating that education into practice. Care went into framing who the new, post-war public servant ought to be. The first post-1945 annual report of the Public Service Board noted a 'distinct change' in the functions of government during the Second World War. This change was characterised as a move from 'regulation' to the emerging 'positive and constructive responsibilities' of government. Further, 
the imperative was to explain these new responsibilities to a public that was, as a whole, increasingly implicated in its business, from welfare to health, from saving to spending. In 1947, the Board presented its new identikit for the type of officer appropriate to these demands:

men must have an opportunity of executive practice and ... to make mistakes before the age of 30 if they are ever to reach the ranks of successful executives. Delay in giving this experience often means that an officer is called on to take an important executive post at a time when he has lost the mental resilience which would make him fully effective. ${ }^{45}$

While much of this formulation was borrowed from early British advocacy (the threshold of 30 came from W.H. Beveridge in 1920 and was quoted by Bland), the emphases were distinct. The capacity to endure inter-war boredom became the post-war challenge of individual responsibility, to muster 'mental resilience'. The test of democracy was now a more specifically defined task of framing policies which could secure popular consent. Equally marked was an implicit break from the established Australian model of public service security as a reward for military service. Gavin Long has calculated that the average age of enlisted men in 1940 was 27, and even allowing for the impact of conscription in 1942, the new, rising public servant was clearly not intended to build on the ranks of such men. ${ }^{46}$ The public service was to make a generational and attitudinal leap with an ethic embellished in the 1948 Public Service Board report:

He (the ideal public servant) is intelligent but with a full share of earthiness. He thrives on the gross air of everyday affairs. He has the common touch ... he is a well-rounded, well-balanced man, broadbacked, with a certain simplicity of nature and the sense of proportion that goes with a sense of humour.

The profile went on, concluding with 'we are looking for the sort of youngster who, with right handling, great care and great patience, will turn out sometime in his thirties or forties to be that sort of man' $^{\prime}{ }^{47}$

This culture of carefully cultivated generalist professionalism sought a balance between qualities of personality and capacities of management. It envisaged officers who would back-fill the paths forged by the dwarfs and their like, and build a service that matched the changes they represented. This is one reason why the 'seven dwarfs' mattered so much in the dinner party conversations among those who were of their age, and defined themselves through what this select, and selected, company stood for. And in this process of consolidation, other resistances

45 Public Service Board, Twenty-Third Annual Report (Canberra: AGPS, 1947), 7.

46 G. Long, To Benghazi (Canberra: Australian War Memorial, 1952), 58.

47 Public Service Board, Twenty-Fourth Annual Report (Canberra: AGPS, 1948), 5-6. 
relaxed. As H.F. Whitlam noted in the first Garran Memorial Oration in 1959 - a lecture series in itself indicating a CPS keen to reflect on its own evolution - the rising currency of the word 'bureaucracy' was becoming less the 'continental nuisance' Carlyle (and Bland) had dismissed. Its increasing currency indicated 'a public consciousness that more and more government power is concentrated in the public service'. The tasks of effectively handling those 'positive and constructive' interventions in the widening and interdependent fields of social and economic policy had become more generic public service attributes as postwar prosperity settled into its own orchestrated balances and disciplines. Just as the 'public administration' Bland had taught in the inter-war years became the 'political science' of the post-war years - an older instrumentalism giving way to a new amalgam of social, economic and political pressures to be mastered - so did the public servant settle into more sophisticated practices of (in Hasluck's formulation) training 'political energy into the chosen direction' ${ }^{48}$

In the expansion of the post-war CPS - even despite Pinner's stringency - from 12 departments in 1939 to twice that number and nearly 160,000 under the Public Service Act in 1957, the time available for 'right handling' was both scarce and frugally bestowed. ${ }^{49}$ The truth of Wilson's advice to Tange on the necessity of inter-departmental rivalry was hammered home in a tight control of staffing, let alone innovation, however much the actual composition of the service might have become steadily younger, better paid and better educated. But something of its goals can be glimpsed in the foundation of the Australian Administrative Staff College in 1957, by then expressing a concept of professional administration that united both public and private sector officers in new tasks of what was termed 'statecraft'. Aspiring officials were to be assessed on their capacity to take 'maximum responsibility' as individuals called upon to judge and act, to delegate and manage the spread of talents beneath them, and to apply the precepts of vocational guidance and aptitude testing in acheiving a more subtle mix of task and personality in the service. ${ }^{50}$

A similar framework informed the hearings conducted in the late 1950s by the Committee of Inquiry into Public Service Recruitment, chaired by Sir Richard Boyer, as it tackled the task of developing a senior 'administrative civil service' appropriate for the times, while also noting that the prejudices against such a stratum had scarcely altered since the war. Boyer's report made a strong case for recognition of a 'liberal education' alongside the dominance of economics as a suitable training for a 'second division' of administrative officers. 'Equality of opportunity', the report argued, could no longer be simply addressed by

48 Scott and Wettenhall, 'Public Administration as a Teaching and Research Field', 461.

49 These figures are taken from the Report of the Committee of Inquiry into Public Service Recruitment (Canberra: APGS, 1959), 9.

50 D.B. Copland, Administrative Staff Training: A New Frontier in Education (Melbourne: Cheshire, 1957), 20, 22 . 
recruitment 'from below' in a society in which access to education was greatly expanding. The opportunities that could be safely bestowed on the 'clever sons of workers' now had to be spread across a citizenry created by prosperity and its wise government. ${ }^{51}$ And the responsibilities of such government equally centred on economic stability and all that was associated with a 'full employment goal and reality' - the promise of prosperity (and its challenges to recruitment for what was still an often disparaged public service) on the one hand; the prospect of inflationary and growth-induced pressures (and their associated demands on public policy) on the other. ${ }^{52}$

Both the interests and pressures encompassed in Boyer's consultations and final report exemplified the Keynesian contract in operation into the 1950s and later. That contract, clearly, had its strengths - and Boyer's call for the more systematic recognition of education and talent was one element of the commitment to public sector reform it hoped to support. But the report and its reception also reflected the boundaries within which that reform might occur. A course at the Staff College went to only a few, and several of Boyer's recommendations including to end the marriage bar for women - were largely dismissed as 'overly theoretical', and likely to upset the fragile balance of roles and responsibilities in the labour market as well as in government. The spirit of Boyer's inquiry was only 'slowly and unspectacularly' implemented by the Public Service Board, largely under Wheeler's influence, through the 1960s. ${ }^{53}$

Each dwarf-and each mandarin - had their own perspectives on such challenges. As secretary of the Department of Labour and National Service, for example, Bland (the younger) was - as Tom Sheridan notes - interventionist in everything from executive government and the secret surveillance of industrial activists through to the determination of wage awards and trade union governance. ${ }^{54}$ Bland is perhaps the least frequently mentioned/remembered of the dwarfs, in part because of his very equivocal relationship to Canberra - which he found 'incestuous', and prone to make a 'song and dance' about policy - and because of his predisposition to step outside the world of the bureaucrat, believing that 'an awful lot can be achieved by having quiet lunches with people, going for walks in gardens and not telling the world what one is doing until the time is right ${ }^{\prime} .{ }^{5}$ In another perspective on the terms of rivalry, it is revealing that when Wheeler and Bland were under close consideration to succeed Dunk at the Public Service Board, Bland was dismissed as too combative and lacking

\footnotetext{
51 Committee of Inquiry into Public Service Recruitment, Report, 10.

52 Ibid., 9.

53 See G. Caiden, 'Administrative Reform', Australian Journal of Public Administration, 29, no. 3-4 (1980), 441.

54 T. Sheridan, 'Regulator Par Excellence: Sir Henry Bland and Industrial Relations 1950-1967', Journal of Industrial Relations, 41, no. 2 (1999), 228-55.

55 J. Farquarson, 'Sir Henry Bland (1909-1997)', Canberra Times, 13 November 1997, 11.
} 
in 'the intellectual integrity which is the prime quality required'. ${ }^{56}$ Held in this balance were those elements of personal style, of the specific structures of government and policy networks, and of the politics of bargaining in general, which clearly shaped the work of the dwarfs and gave them distinct Australian inflections. Bland had close relations with his first minister, Harold Holt, with the National Civic Council of right-wing Catholic trade unionists, and with the then president of the Australian Council of Trade Unions, Albert Monk, but less so with Holt's successor, William McMahon, and the more fractured, public, controversialist style of politics that characterised the second half of the 1960s. He was, like each of the dwarfs in their own ways, of a time that was passing.

It is important to note again - as with Perkin's sense of the political alignments of public sector professionalism - that the Australian aproach to cultivating these generalised skills of oversight and management reflected wider patterns. In his study of Whitehall, for example, Peter Hennessy observes similar processes in Britain. Hennessy's account suggests that while the UK Home Civil Service had a jump on its Australian counterpart in thinking of the 'higher bureaucracy ... as a distinctive career' in the inter-war years, similar ideals, constraints and reservations were prevalent as it adjusted to post-war circumstances. Between the wars, Sir Warren Fisher, permanent secretary of the Treasury, still held to the view that taking bright young things fresh from civil service exams was no way to build real bureaucratic leadership: 'if you do that they will then get to work and take their little pens in their infant hands and will write away little criticisms of every sort and kind, very clever ones no doubt, but there is no training for constructive work'. It was only under the pressure of the Second World War, Hennessy argues, that Whitehall - like Canberra - became of necessity 'an adventure playground for all the talents'. Given the interconnections of British elites, and perhaps the immediacy of the threat, Britain benefitted from a more systematic recruitment of experts than occurred in Australia.

Yet it was still the case that a range of factors saw the gains in 'fluid, capable and managerial' capacity in government won during the war sacrificed in the post-war years. The 'type' of public servant to be preferred in post-war Britain, whether under Labour or the Conservatives, was not - Hennessy insists - a figure of specialisation or expertise, of the kind that had found a place during the pressures of total war mobilisation. They were instead those who assumed a largely manufactured mantle of general professionalism, capable of containing processes of adjustment to post-1945 circumstances that ranged from anxieties over upward class mobility to concerns over the expanding welfare state. Overall, Hennessy argues, the result in discarding specific expertise was "probably the greatest lost opportunity in the history of British public administration' ${ }^{57}$

56 Dunk to Crawford, 31 August 1959, Crawford Papers, NLA MS 4514, Box 81, folder headed 'Staffing Wheeler $\mathrm{F}^{\prime}$.

57 P. Hennessy, Whitehall (London: Secker and Warburg, 1989), 54, 120, 156. 


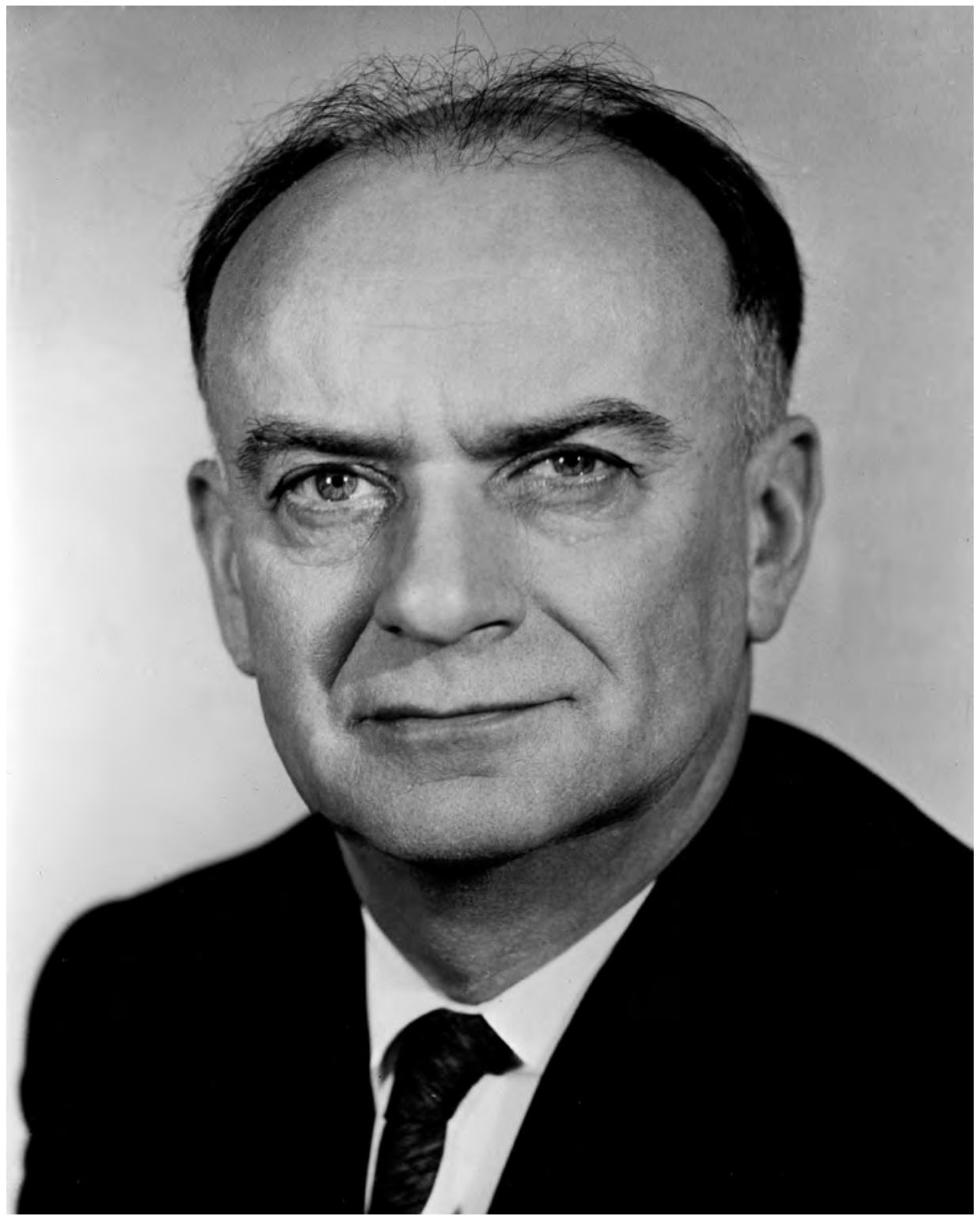

\section{Sir Henry Bland, 1966}

Source: National Archives of Australia, A1200, L58484

Does this judgment apply to Australia? Is it part of the legend, and the legacy, of the 'seven dwarfs'? In this survey, I have attempted only to suggest some themes that might be borne in mind in seeing a pattern in the more detailed accounts of careers and contributions that follow. Certainly, as noted at the outset, the land of the dwarfs was to be comprehensively challenged by the 1980s, and was 
already under siege by the 1970s. It was threatened by a range of pressures, to some extent coalescing around another crucial change of government in 1972. Labor returned to power in that year with its own suspicions of officials still captive to 23 years under the Coalition, and with its own aspirations for a more socially representative bureaucracy, extending beyond the 'well-balanced, broadbacked man' to a figure, or figures, more attuned to the diversity then increasingly characterising Australian society. The 'impartiality' of a permanent head began to seem less than an asset in managing this transition, or in being accountable to governments embracing a more explicit mandate for change. Again, however, the question of balancing factors internal and external to the CPS should be taken into account in making sense of these pressures.

The dwarfs, while path-breakers in many ways, were also well-matched to the tasks their times gave them - to that balance of judgment, attitude and influence required to regulate that restless beast, the fully employed Australian economy. Bland faced industrial issues associated with those pressures very directly, if discretely, as did Coombs, adjusting monetary mechanisms as governor of the Commonwealth (later the Reserve) Bank in Sydney. In Canberra, the Treasury was at it all the time. Sir Richard Randall's triumph, as its secretary, was said to be a campaign to cut income tax, and his responsibility for the phrasing of budget speeches that got the fiscal messages of admonition and exhortation right for a restless electorate. ${ }^{58}$ External Affairs wrestled with an attempt to boost its own standing in the ruck of public service recruiting, but its cultivation of a diplomatic intake in a highly competitive employment market never quite achieved the balance sought between generalist skills, the right 'type', and a representative range in backgrounds to diffuse easy jibes at elitism. Across the board, it remained the case, as Ruth Atkins observed, that, in the rapidly expanding national capital, the concept of 'the public' morphed seamlessly into that of the 'public servant' as a custodian, a safe pair of hands, a continuity to be balanced against the more uncertain commodity of 'the private', whether in politics, pressure groups or policy. Increasingly becoming the home for central agencies, and for the deals within government, the city itself boomed, acquired sophistication, and exemplified a tendency for debates over priorities and values to be cast in terms of disputes between departments rather than in society or the economy beyond them. ${ }^{59}$ As critics were to note into the 1960 s - confirming Downing's alarm - Canberra seemed locked in a spiral of 'few industries and too much industry', becoming more insular, and insulated, in this growth. ${ }^{60}$

58 Bulletin, 14 November 1970; see generally G. Whitwell, The Treasury Line (Sydney: Allen and Unwin, 1986).

59 R. Atkins, The Government of the Australian Capital Territory (St Lucia: University of Queensland Press, 1978), 8.

60 Bulletin (Sydney), 24 April 1957, 6. 


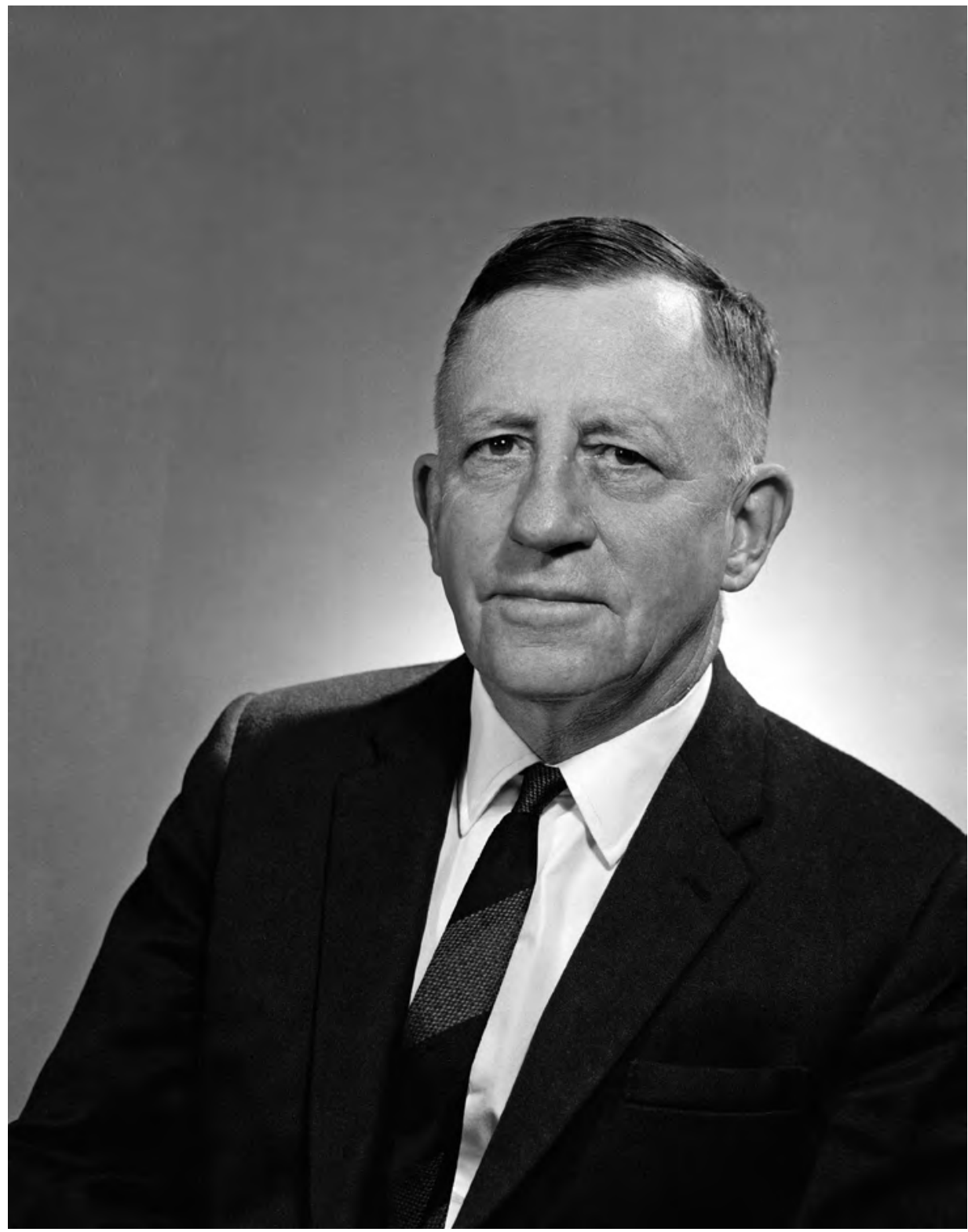

Sir Richard Randall, 1966

Source: National Archives of Australia, A1200, L57983

Rivalries remained intense. Bastions such as the Commonwealth Club grew to accommodate, diffuse and civilise the jostling of many of the mandarins engaged in these processes (Crawford, Dunk, Brown and Tange were among its earliest members in 1955, although it remained more a roost for External 
Affairs officials - perhaps self-consciously a 'flock of homeless people' - than for other departments well into the 1960s). And it was perhaps from the vantage of this select club that Wheeler (a member since 1960) observed that 'the attitude, behaviour and standards of the corps of Permanent Heads is of far greater importance in determining the tone and ethos of higher Public Service than all the rules and regulations' ${ }^{61}$ Style, again, mattered - by now, it was a badge of acceptance.

There were, however, increasing signs of fracture within this landscape. Boyer's unaddressed recommendations nagged - how should the public service of the late 1940s and 1950s adjust to the changing world of the 1960s? An increasingly analytical academic and journalistic perspective on the CPS and on policy development more generally began wondering whether the business of government, as it increasingly intersected with a diversification of social aspirations and attitudes, was perhaps no longer best served only by the priorities of economic management, but needed to take advice from other fields. ${ }^{62}$

Even within the domain of economics there was pressure. Crawford, for example, sought, through his participation in the Committee of Economic Enquiry established by the Menzies Government in 1963 under the chairmanship of industrial executive (Sir) James Vernon - to expand the capacity of economic policy to engage with the intersecting dynamics of demographic trends, educational opportunities, public health, physical infrastructure constraints, natural resource possibilities, and industrial productivity in Australia. Released in 1965, the Vernon Report espoused a concept of 'growth' which, beyond its material benefits, 'endows the community with a sense of vigor and social purpose'. 'Growth' was the concept that, the committee argued, 'will make it easier for the community to exercise an even more fundamental kind of choice' about the conduct of their lives. ${ }^{63}$ But it also required a more concerted program of planning, and this was the core recommendation from Vernon that the government and the Treasury in particular rejected. In this stand-off came perhaps the most public display of the rivalries and tensions that had always nagged away at the company of dwarfs, but now became public, and fed into public questioning.

It was the 'mauling' of the Vernon Report - despite it being, as Crawford noted, only 'mildly critical' of the government's record in economic management - that prompted the Financial Review in 1965 to bring the idea of the seven dwarfs

61 Wheeler, 'The Professional Career Public Servant', 173.

62 See B. Juddery, At the Centre: The Australian Bureaucracy in the 1970s (Melbourne: Cheshire, 1974), 77; also D. Glover, 'National Complacency? Australia in the Later Menzies Years: The Evidence of Prospect, The Observer and The Bulletin, 1958-1964', Journal of Australian Studies, 54/55 (1997): 176-87.

63 Committee of Economic Enquiry, Report of the Committee of Economic Enquiry, Vol. 1 (Canberra: AGPS, 1965), 29. 
back into the spotlight. The Report was not asking for much in terms of an independent group of economic policy advisers. It was trying, perhaps, to achieve what Allen Brown had hoped to secure in the early 1950s, in salvaging the best of Post-War Reconstruction's experts for the Prime Minister's Department before they were scattered to other departments. Yet even in this tussle over the Vernon Report, the Financial Review concluded, 'the seven dwarfs ... have proven to be a most unradical group with a decided bias towards conservatism'. As individuals, in their internalised and externalised stances of (in Wheeler's term) 'self-denial', they had not sought to recast the structures of government. Nor in 1965 would they enter too far into public debate - that was not their role. ${ }^{64}$ They tended, instead, to hold tight to the established places.

In the mid-1960s, then, the tensions that had - as Nethercote suggests - been with the dwarfs from the start, in their backgrounds and their dispositions, remained salient. But where once those tensions had been contained within a series of assumptions about the fit between the role and figure of the public servant and the settings of public policy, they now were steadily exposed by changes in those settings. Individual careers were far from over, but they were diversifying. Crawford was at ANU, building the research culture on big issues he had long sought within government; Brown spent a decade in diplomacy; Wilson became chairman of the Commonwealth Bank and QANTAS; Bland retired to corporate directorships, though he found time to conduct several government reviews and, briefly, to chair, and cut, the ABC. Coombs left the Reserve Bank in 1968 and became closely associated with several dimensions of the social and cultural questioning in Australia over the following years - in the arts, over the environment, and most particularly in Aboriginal affairs. Wheeler, securing at last the 'glittering prize' of becoming secretary of the Treasury in 1971, would confront a prime minister whom he judged to be breaking with the proprieties that underpinned accountable government. Around Whitlam, as Wheeler despaired, there had clustered an 'ebullient community ... in which groups claim the right to push and act on the basis of self-interest, often using whatever power is to hand regardless of the consequence to others' ${ }^{65}$ This was no way to behave; it was a fracture in all that the age of the seven dwarfs had represented - or a loss of control over the forces they had always feared.

In 1958, Sir Robert Garran assured readers of his memoirs that the national capital had long passed the point where its petty insularity could be evoked by the motto, 'by their incomes you shall know them' ${ }^{66}$ But with the passing of the dwarfs it was not just the austere and unimpeachable authority of a few wise and feared permanent heads that was slowly, at first imperceptibly,

64 Financial Review, 12 November 1965, 3.

65 Wheeler, 'The Professional Career Public Servant', 179.

66 R. Garran, Prosper the Commonwealth (Sydney: Angus and Robertson, 1958), 286. 
being consigned to history. It was also a way of characterising a contract of government, and a figure to embody it, which set a distinct stamp on formative processes of post-war national development. It is hard to imagine the dwarfs enduring the charge of presiding over a "she'll-be-right-mate" management and work style' in the 1980s. It is equally hard to imagine that such a charge would ever have been made against them in their time; Wheeler, as Ian Hancock notes in his chapter, stared down parliamentary scrutiny of his actions. That parliament would presume to push even further into the actions of officers at much lower levels within departments was inconceivable - then. Yet, if the 'age' of such figures now seems discontinuous with much that has followed, it is worth checking such nostalgia, or such dismissal, to ask instead what rose and fell with them in the work of government, and created the space in which such change was possible. The biographically informed chapters that follow go a long way in teasing out the extent to which the seven dwarfs were not simply a settled company in a faraway land, but a group characterised by tensions, rivalries, and 'styles' that were a part of transitions with long-term significance. 
This text is taken from The Seven Dwarfs and the Age of the Mandarins: Australian Government Administration in the Post-War Reconstruction Era, edited by Samuel Furphy, published 2015 by ANU Press, The Australian National University, Canberra, Australia. 